Article

\title{
Digital Disinformation and Preventive Actions: Perceptions of Users from Argentina, Chile, and Spain
}

\author{
Jordi Rodríguez-Virgili *, Javier Serrano-Puche and Carmen Beatriz Fernández \\ University of Navarra, 31009 Pamplona, Spain; E-Mails: jrvirgili@unav.es (J.R.-V.), jserrano@unav.es (J.S.-P.), \\ cbfer@datastrategia.com (C.B.F.) \\ * Corresponding author
}

Submitted: 30 July 2020 | Accepted: 2 October 2020 | Published: 3 March 2021

\begin{abstract}
This article explores audience perceptions of different types of disinformation, and the actions that users take to combat them, in three Spanish-speaking countries: Argentina, Chile, and Spain. Quantitative data from the Digital News Report (2018 and 2019), based on a survey of more than 2000 digital users from each country was used for the analysis. Results show remarkable similarities among the three countries, and how digital users identically ranked the types of problematic information that concerned them most. Survey participants were most concerned by stories where facts are spun or twisted to push a particular agenda, followed by, those that are completely made up for political or commercial reasons, and finally, they were least concerned by poor journalism (factual mistakes, dumbed-down stories, misleading headlines/clickbait). A general index of "Concern about disinformation" was constructed using several sociodemographic variables that might influence the perception. It showed that the phenomenon is higher among women, older users, those particularly interested in political news, and among left-wingers. Several measures are employed by users to avoid disinformation, such as checking a number of different sources to see whether a news story is reported in the same way, relying on the reputation of the news company, and/or deciding not to share a news story due to doubts regarding its accuracy. This article concludes that the perceived relevance of different types of problematic information, and preventive actions, are not homogeneous among different population segments.
\end{abstract}

\section{Keywords}

Argentina; audience; Chile; digital journalism; digital media; disinformation; fake-news; information vulnerability; misinformation; Spain

\section{Issue}

This article is part of the issue "Disinformation and Democracy: Media Strategies and Audience Attitudes" edited by Pere Masip (University Ramon Llull, Spain), Bella Palomo (University of Málaga, Spain) and Guillermo López (University of Valencia, Spain).

(C) 2021 by the authors; licensee Cogitatio (Lisbon, Portugal). This article is licensed under a Creative Commons Attribution 4.0 International License (CC BY).

\section{Introduction}

In recent years, academics and the media have been paying attention to the phenomenon of disinformation (Freelon \& Wells, 2020; McKay \& Tenove, 2020). The fact that disinformation poses a threat to democratic institutions has contributed to mounting concern regarding this problem (Miller \& Vaccari, 2020). Disinformation is a modality within a broader field called 'problematic information' (Jack, 2017), which includes various types of information that are considered inaccurate, misleading, or found to be improperly or totally manufactured. Although it is true that this type of media is not novel, today's information ecosystem is without precedent, due to its sheer scale and scope. This fosters new ways in which problematic information can be created, circulated, and received by users, increasing its potential effects (Lewandowsky, Ecker, \& Cook, 2017). Said information ecosystem is technological in nature, but it also has political, social, and economic implications, giving 
rise to what Wardle and Derakhshan (2017) have called an 'information disorder.'

\section{Theoretical Framework}

The academic literature on disinformation has grown remarkably in the last decade (Ha, Perez, \& Ray, 2019). Following Freelon and Wells (2020), two main areas of enquiry are particularly worth noting: On the one hand, research that focuses on content, and on the other, reception studies. In the following pages we analyze these areas in detail.

\subsection{Types of 'Problematic Information'}

Regarding content, various types of information are included under the paradigm of 'problematic information.' Among them, the term 'fake news' has become the most popular. However, Egelhofer and Lecheler (2019) caution that the term fake news should not be used to group instances of falsehood indiscriminately. As the concept should differentiate between fake news as a genre and the fake news label as applied to specific news by political figures to discredit journalism (Khaldarova \& Pantti, 2016). For this reason, it is preferable to broaden the range of concepts included in this phenomenon. Allcott and Gentzkow (2017) pointed out six different types of problematic information:

1) Unintentional reporting mistakes; 2) rumours that do not originate from a particular news article; 3 ) conspiracy theories (these are, by definition, difficult to verify as true or false, and they typically originate from those who believe them to be true); 4) satire that is unlikely to be misconstrued as factual; 5) false statements by politicians; and 6) reports that are slanted or misleading but not outright false. (p. 214)

In addition, Tandoc, Lim, and Ling (2018), through a bibliographic review of the academic literature, identify six types, partially coinciding with the abovenews satire, news parody, fabrication, manipulation, propaganda, and advertising-which they organize along two dimensions according to their level of facticity and deception.

According to the High Level Expert Group on Fake News and Disinformation, designated by the European Commission, disinformation includes "all forms of false, inaccurate, or misleading information designed, presented and promoted to intentionally cause public harm or for profit" (High Level Expert Group on Fake News and Disinformation, 2018, p. 5). This definition introduces a parameter that helps catalogue the cast of disinformation genres, namely the content creator's motivation. Indeed, the intention to cause harm or to seek profit is a vector that allows malicious disinformation and deliberately polarized content to be distinguished from other situations where online content may be untruthful, such as satirical news or journalistic pieces that turn out to be imprecise due to lack of professionalism. Although such pieces do not intend to cause deception or confusion, this may in fact, be the result. The content itself, its factuality, the lexical and syntactic features within it, and any evidence presented might inadvertently cause confusion. The sources that are consulted for these journalistic pieces, the possible intentions of the issuing agent, and other structural elements (such as URL, or website transparency), allow for the establishment of a taxonomy of modalities of false content that contrast with the 'real news.' These range from fabricated news to disguised advertising, including also parodic news or information from hyperpartisan sources (Molina, Sundar, Le, \& Lee, 2019). Therefore, we ask:

RQ1: What are the types of disinformation that raise more concern among digital users?

\subsection{Factors that Influence Disinformation Reception}

Firstly, and from a macro point of view, researchers have centred on which structural conditions of countries can lead to a greater or lesser resilience towards disinformation. Following Humprecht, Esser, and Van Aelst (2020), carried out cross-national comparative research in 18 countries, these factors include the country's level of social polarization, political populism, trust in the news, or the strength of the public media, among others.

Descending to the individual level, a review of the literature suggests that exposure and vulnerability to disinformation are mediated by several different factors: political ideology, age, gender, and level of interest in public affairs. Regarding ideological self-positioning, some studies agreed that the American right-wing is substantially more vulnerable to disinformation attacks, and more likely to accept them, than the left-wing. It is an 'ideological asymmetry' (Freelon et al., 2020), showed in two different dimensions: First, the content dimension, wherein disinformation providers produce vastly more conservative-oriented messages than liberal ones (Allcott \& Gentzkow, 2017; Howard, Ganesh, Liotsiou, Kelly, \& Francois, 2018; Mckay \& Tenove, 2020); second, the reception dimension, showing that conservatives are also more likely to engage with the disinformation messages that target them than liberals (Grinberg, Joseph, Friedland, Swire-Thompson, \& Lazer, 2019; Hjorth \& Adler-Nissen, 2019).

Regarding age as a significant variable in relation to disinformation reception, Guess, Nagler, and Tucker (2019) identify a strong age effect, through their research on individual-level characteristics associated with sharing false articles during the 2016 US presidential campaign. Respondents in an older age category were more likely to share fake news than respondents in the next-youngest group. Overall, users over 65 years old, shared nearly seven times as many articles from fake news domains as the youngest age group. Other 
studies, such as that of Serrano-Puche, Fernández, and Rodríguez-Virgili (2021), using the Venezuelan political landscape as a case study, have analysed vulnerability to disinformation as dependent, besides age, on educational level and the main source of information (analogue or digital).

The relationship between gender and attitudes towards disinformation has been understudied and lacks conclusive results. Studies such as Reuter, Hartwig, Kirchner, and Schlegel (2019) have found significant differences in Germany among men and women regarding perceptions of disinformation's effects on society and the agents that cause it. However, gendered differences were not found among ways to react to disinformation. In a similar vein, in a survey with Portuguese college students, Morais and Cruz (2020) found gender differences in the use of media and information consumption, but not in the skills to distinguish between credible and false sources of information.

Regarding interest in political matters, research indicates that using social media for news can lead to the spread of misinformation, albeit indirectly, due to its association with individuals' political participation (Valenzuela, Halpern, Katz, \& Miranda, 2019). Although being politically engaged does not make people more or less likely to be misinformed, active users are more likely to share inaccurate contents than those who are less politically engaged (Bail et al., 2020). Other studies indicate that political participation can promote the formation of closed groups in which disinformation is more likely to be sent and received. In this way, with the consolidation of such polarized groups, the opportunity to access divergent information diminishes, favouring selective exposure to partisan sources (Iyengar \& Hahn, 2009; Lazer et al., 2018). As with selective exposure, motivated reasoning can contribute to an individual becoming misinformed (Scheufele \& Krause, 2019). When users engage in goal-directed processing of new information to protect preexisting values, beliefs, and ideologies (Kunda, 1990), and when such directional goals influence reasoning processes, individuals become prone to 'biased assimilation' (Lord \& Taylor, 2009). This is the tendency to privilege information that is consistent with one's predispositions, discrediting information that seems contradictory. Giglietto, Iannelli, Valeriani, and Rossi (2019) affirm that those who receive disinformation can in turn become its propagators-whether intentionally or not. This might generate propagation cascades where the intention of the 'injector' does not determine the future evolution of the false information cycle, meaning that what was born as a parody or a journalistic error can end up being amplified for manipulative purposes.

Taking all this into consideration, we also ask:

RQ2: Do sociodemographic factors, such as political leaning, age, gender, and interest in political news, influence the perception of disinformation?

\subsection{Coping with Disinformation: The Role of Media Literacy}

The phenomenon of disinformation requires a reconceptualization affecting news media practices, media policies, and how media literacy initiatives are designed and mapped out. In this sense, it is necessary to situate media literacy within an ample framework of actions, centring in the defence of the public sphere and common interests. According to Lazer et al. (2018), there are two categories of interventions that might be effective to stop the flow and influence of disinformation: "(i) those aimed at empowering individuals to evaluate the fake news they encounter, and (ii) structural changes aimed at preventing exposure of individuals to fake news in the first instance" (p. 1095).

Regarding the first category, there is an academic consensus that citizens are largely uninformed due to their inability to critically examine and evaluate information (Scheufele \& Krause, 2019). Although it may also be due to the aforementioned reasons for cognitive biases, there is no doubt that a part of the disinformation problem is citizens' low level of media literacy. Starting from the basic definition that media literacy is "the ability of a citizen to access, analyze, and produce information for specific outcomes" (Aufderheide, 1993, p. 6), it can be concluded that it is the evaluation skill that poses the most relevant challenge for disinformation, as those with limited ability to evaluate "cannot distinguish dated, biased or exploitative sources" (Livingstone, 2004, p. 6). Therefore, as Klurfeld and Schneider (2014) point out, "the ultimate check against the spread of rumour, pernicious falsehood, disinformation, and unverified reports masquerading as fact" is a "generation of astutely educated news consumers" who can "identify for themselves fact-and-evidence-based news and information" (p. 19).

In regards to the actions taken by citizens to combat disinformation, a review of the literature allows us to identify some recurring measures. In a qualitative study with 71 American users from different cities, Wagner and Boczkowski (2019) identify as main measures: drawing upon the experience and knowledge to assess news quality, triangulating sources, fact-checking, seeking for repetition of information across outlets, consumption of cross-ideological sources, and relying on certain personal contacts on social media who are perceived as good assessors of news quality. For their part, Tandoc, Ling, Westlund, Duffy, Goh, and Zheng (2018) utilize a survey of 2,501 Singaporeans to propose a conceptual framework to understand how individuals authenticate the information they encounter on social media. The results suggest that users rely on their own judgment of both the source and the message, and when this does not adequately provide a definitive answer, they turn to external resources to authenticate news items (from their social sphere or other institutional sources). On the other hand, fact-checking can be incidental and can simply 
arise from the process of interacting with friends or consuming media.

The option of consulting a fact-checking website is not frequent among Portuguese university students, according to Figueira and Santos (2019). When in doubt about the veracity of a news item, the young people surveyed were more likely to check various sources, in addition to consulting trustworthy organizations. Finally, in a survey among Germans on 'fake news' perceptions, Reuter et al. (2019) indicate that even though about half of the respondents $(48 \%)$ had noticed fake news, most participants report never having liked, shared, or commented on it.

Since user response is important in the spread and control of fake news on social media, finally we ask the following:

RQ3: What are the most common actions taken by Internet users to avoid being deceived by disinformation?

\section{Method}

\subsection{Context}

This work is part of a line of research by the authors that seeks to broaden the understanding of digital information consumption. Most empirical studies to date have a narrow geographical perspective, which limits the universality of inquiry in those topics, and suffer from a lack of contextualization (Rojas \& Valenzuela, 2019). Thus, the geographical focus of our inquiry is centred in Iberoamerica, which encompasses Latin America and Spain (Fernández \& Rodríguez-Virgili, 2019; Serrano-Puche et al., 2021; Serrano-Puche, Fernández, \& Rodríguez-Virgili, 2018). A region where the academic literature on disinformation has grown in recent years (Guallar, Codina, Freixa, \& Pérez-Montoro, 2020), but which still lacks empirical studies. Our analysis focuses on three Spanish speaking democracies with high Internet penetration rates, ranging from $77.5 \%$ of the population in Chile to $92.5 \%$ and $93.1 \%$ in Spain and Argentina, according to data from Internet World Stats (2019; Table 1).

Considering our objective to develop the understanding of disinformation in Iberoamerica, one thing to note is that countries such as Argentina, Chile, and Spain are experiencing symptoms of information disorder as do the other countries of the global North
(Valenzuela et. al., 2019; Wardle \& Derakhshan, 2017). The Reuters Institute Digital News Report (Newman, Fletcher, Kalogeropoulos, \& Nielsen, 2019) shows a generalized and steady decline in the average level of trust in the news and in traditional media worldwide. In addition, these three countries have experienced recent electoral or post-electoral contexts: Chile held presidential elections in 2017, Argentina in 2019, and Spain held two general elections in 2019. Objectives will be addressed in this comparative study using a most-similar systems approach (Meckstroth, 1975).

\subsection{Sample}

This work was developed from surveys carried out annually by the Reuters Institute Digital News Report (Newman, Fletcher, Kalogeropoulos, Levy, \& Nielsen, 2018; Newman et. al., 2019), an international study on the consumption of digital information coordinated since 2012 by the University of Oxford, which currently includes 40 countries. For this specific study, surveys from the years 2018 and 2019 were consulted. Specifically, this study analysed user samples from Argentina (2018: $n=2,012 ; 2019: n=2,006)$, Chile (2018: $\mathrm{n}=2,008 ; 2019: \mathrm{n}=2,004)$, and Spain (2018: $\mathrm{n}=2,023$; 2019: $\mathrm{n}=2,005$ ).

The participants of the Digital News Report are adult Internet users who have consumed news in the last month, which serve as representatives of the connected population according to sociodemographic and geographic criteria. The data has been weighted according to official censuses and data accepted by the industry, and classified by age, sex, region, newspaper reading, and educational level, in order to better reflect the population of the three countries analysed. However, one should bear in mind that although these samples represent the digital population well, they do not necessarily represent the general population, and this can be considered a methodological limitation of the research.

\subsection{Questionnaire and Variables}

The online questionnaires cover a wide range of questions about news consumption, from which this research selected those that relate to disinformation. Questionnaires were not identical for both years. First, we used a question related to the different types of problematic information, from the 2018 survey:

Table 1. Penetration of the Internet in analysed countries.

\begin{tabular}{lccc}
\hline Country & Population & Internet Users & Penetration Rate \\
\hline Argentina & $44,688,864$ & $41,586,960$ & $93.1 \%$ \\
Chile & $18,197,209$ & $14,108,392$ & $77.5 \%$ \\
Spain & $46,441,049$ & $42,961,230$ & $92.5 \%$ \\
\hline
\end{tabular}

Source: Internet World Stats (2019). 
To what extent, if at all, are you concerned about the following:

- Stories where facts are spun or twisted to push a particular agenda

- Stories that are completely made up for political or commercial reasons

- Poor journalism (factual mistakes, dumbed-down stories, misleading headlines/clickbait)

- The use of the term fake news (e.g., by politicians, others) to discredit news media they don't like

- Headlines that look like news stories but turn out to be advertisements

- Stories that are completely made up to make people laugh (satire)

From the 2019 survey we used a question about the different actions that users can take to protect against disinformation:

Have you done any of the following in the last year? Please select all that apply.

- I checked a number of different sources to see whether a news story was reported in the same way

- I decided not to share a news story because I was unsure about its accuracy

- I discussed a news story with a person I trust because I was unsure about its accuracy

- I stopped paying attention to news shared by someone because I am unsure whether I trust that person

- I stopped using certain news sources because I was unsure about the accuracy of their reporting

- I started relying more on sources of news that are considered more reputable

Considering our review of the literature and following the aforementioned research questions, the analysis of the answers takes into account sociodemographic variables such as age, gender, political leaning, access to, and interest in news.

\subsection{Procedure}

The fieldwork was carried out between the end of January and the beginning of February of both years, 2018 and 2019. It was conducted by the firm YouGov, which sent an invitation via email for users to complete an online poll.

\subsection{Analyses}

First, within each country, we identified what the participants' most prevalent concerns were regarding disinformation. Differences were tested with McNemar's test, after which Chi-squared tests were performed to identify differences according to country, gender, and political self-positioning. The association between the concerns and age was tested with Spearman correlations. Finally, we created a composite measure of 'Concern about disinformation' based on the answers to the 6 items. A multivariate linear regression was then performed with this composite measure as a dependent variable, and different independent variables such as demographics and others related to news and politics. We performed the same analyses for the variables regarding actions against disinformation.

\section{Results}

In response to the aforementioned research objectives and questions, results are presented below under two main headings. First, we analyse which types of problematic information are of most concern for digital users in Argentina, Chile, and Spain (RQ1). The most common measures adopted by these users to combat disinformation (RQ3) are presented below. In both cases, and from a comparative perspective, the incidence of sociodemographic factors (RQ2) on the phenomenon of disinformation is examined.

\subsection{Concerns about Disinformation}

According to the Digital News Report of 2018, in general, the phenomenon of disinformation is a major concern among digital users in Argentina (60\%), Chile (66\%) and, to a greater extent, in Spain (69\%), but the different manifestations of disinformation do not worry users to the same degree (Newman et. al., 2018). The questionnaire probes a range of six types of problematic information to which the interviewee assigns a greater or lesser level of concern. It should be noted that for the three countries, the final user ranking of problematic information is very similar (Table 2). The most worrying type of problematic information within the three countries analysed is "news that are created or altered in favor of a particular agenda" (77\% of Spaniards, $74 \%$ of Argentinians, and $69 \%$ of Chileans). In the second spot, citizens placed "news that are completely invented, with political or commercial motivations" (in both Argentina and Spain, 73\% of surveyed were concerned, with slightly lower numbers in Chile). In third place, participants selected errors that could be explained by mediocre journalism, such as inaccuracies, wrong or striking headlines that only seek to generate clicks (with $68 \%$ of the participants from these three countries showing concern). Likewise, for the three countries surveyed, the existence of parody news, or those just invented to make people laugh, occupy the last place in the ranking of concerns among those survey participants (with only 29-32\% of participants showing concern for this type of media). News stories that can be considered as covert advertising, straying far from the news, are not reported to be of much concern either.

There does not seem to be a distinctive pattern related to concerns about problematic information when considering the gender of the interviewees (see 
Table 2. Concern about disinformation by country.

\begin{tabular}{|c|c|c|c|c|}
\hline & $\begin{array}{l}\text { Argentina } \\
(\mathrm{N}=2012)\end{array}$ & $\begin{array}{c}\text { Chile } \\
(\mathrm{N}=2008)\end{array}$ & $\begin{array}{c}\text { Spain } \\
(\mathrm{N}=2023)\end{array}$ & $p^{*}$ \\
\hline $\begin{array}{l}\text { Stories where facts are spun or twisted to push a } \\
\text { particular agenda }\end{array}$ & $74 \%^{a}$ & $69 \%^{a}$ & $77 \%^{a}$ & $<.001$ \\
\hline $\begin{array}{l}\text { Stories that are completely made up for political or } \\
\text { commercial reasons }\end{array}$ & $73 \%^{a}$ & $68 \%^{a}$ & $73 \%^{b}$ & $<.001$ \\
\hline $\begin{array}{l}\text { Poor journalism (factual mistakes, dumbed-down stories, } \\
\text { misleading headlines/clickbait) }\end{array}$ & $68 \%$ b & $68 \%^{a}$ & $68 \%^{c}$ & .745 \\
\hline $\begin{array}{l}\text { The use of the term fake news (e.g., by politicians, others) } \\
\text { to discredit news media they don't like }\end{array}$ & $58 \%$ b & $66 \% d$ & $60 \%{ }^{c}$ & $<.001$ \\
\hline $\begin{array}{l}\text { Headlines that look like news stories but turn out to } \\
\text { be advertisements }\end{array}$ & $43 \%{ }^{d}$ & $43 \%^{c}$ & $53 \%$ e & $<.001$ \\
\hline $\begin{array}{l}\text { Stories that are completely made up to make people } \\
\text { laugh (satire) }\end{array}$ & $29 \%$ e & $33 \% d$ & $34 \%^{f}$ & .001 \\
\hline
\end{tabular}

Notes: Question "To what extent, if at all, are you concerned about the following” (answers: Very + Extremely concerned). Within each country, different superscripts indicate a statistically significant $(p<.05)$ difference in percentages, according to the McNemar's test $\left({ }^{a}>^{b}>^{c}>^{d}>^{e}>^{f}\right) .{ }^{*} p$-value of the Chi-squared test for the inter-country comparison. Source: Adapted from the Reuters Institute Digital News Report survey 2018, conducted by YouGov.

Supplementary File, Table A). Instead, when analysing responses to concern about types of disinformation by age group, as shown in Table 3, findings suggest a pattern: in all cases, concern over disinformation increased with age.

When we analyse the concern regarding disinformation according to the reported ideological position (Table 4), as measured by the political self-positioning of the interviewees, we find an interesting pattern in the three countries analysed: those who see themselves as 'left-leaning' tend to worry more about disinformation. This pattern is evident in the three countries analysed and when analysing the forms of disinformation that were considered most worrying.

\subsection{Actions against Disinformation}

There is a similar pattern in the three countries analysed in relation to the actions they take to protect themselves against disinformation (Table 5). The checking of different sources and how they contrast with each other is the main measure that Argentinian (60\%), Chilean (63\%), and Spanish (56\%) respondents take against disinformation. In second place, participants attempt to avoid viralizing news that is not entirely reliable $(52 \%, 50 \%$, and $40 \%$, respectively).

However, although the relative importance attached to the different measures of disinformation is the same, the intensity of the reaction is not equal. There is an important gender gap in the actions taken when faced with problematic information (Supplementary File, Table B).

Although a clear pattern was detected in the three countries (Table 3 ) regarding the direct relationship between age and concern about 'problematic information,' the same does not occur with reported actions to combat disinformation (Table 6). Only in a few cases do we find a significant linear trend. A clear trend was found in Spain, where younger participants reported more frequently discussing news with a person they trust. Another clear trend was found in Chile, where older participants reported a higher incidence of checking different sources and of stopping paying attention to news shared by someone because of being unsure of that person's reliability.

Regarding the relationship between ideological selfpositioning and the different measures to protect against disinformation, divergences are observed (Table 7). In Argentina and Chile, those who declare themselves as being on the left of the political spectrum stop consulting some media when they feel the medium has failed them ( $49 \%$ and $47 \%$, respectively) more often than centrists (39\% and $38 \%$ ) and right-wingers (37\% and $38 \%$ ). Moreover, in Argentina, left-wingers discussed news with a person they trust $(44 \%)$ more often than centrists $(41 \%)$ and right-wingers (32\%).

\subsection{Predicting Concern and Actions}

The composite measure of 'Concern about disinformation' showed a good internal consistency (Cronbach alpha $=.84)$. In the multiple regression to predict this measure (see Table 8), concern about disinformation was higher among women, older participants, those with high interest in political news, left-wingers, and Spaniards.

Regarding actions against disinformation, the internal consistency of the composite measure was lower (Cronbach alpha $=.56$ ), probably due to the fact that these variables were dichotomous. According to the 


\section{COGITATIO}

Table 3. Concern about disinformation by age.

\begin{tabular}{|c|c|c|c|c|c|c|c|c|c|c|c|c|c|c|c|c|c|c|}
\hline & \multicolumn{6}{|c|}{ Argentina } & \multicolumn{6}{|c|}{ Chile } & \multicolumn{6}{|c|}{ Spain } \\
\hline & $\begin{array}{c}18-24 \\
(N=300)\end{array}$ & $\begin{array}{c}25-34 \\
(N=418)\end{array}$ & $\begin{array}{c}35-44 \\
(N=398)\end{array}$ & $\begin{array}{c}45-54 \\
(N=302)\end{array}$ & $\begin{array}{c}55+ \\
(N=594)\end{array}$ & $p^{*}$ & $\begin{array}{c}18-24 \\
(N=281)\end{array}$ & $\begin{array}{c}25-34 \\
(N=416)\end{array}$ & $\begin{array}{c}35-44 \\
(N=357)\end{array}$ & $\begin{array}{c}45-54 \\
(N=361)\end{array}$ & $\begin{array}{c}55+ \\
(N=592)\end{array}$ & $p^{*}$ & $\begin{array}{c}18-24 \\
(N=166)\end{array}$ & $\begin{array}{c}25-34 \\
(N=293)\end{array}$ & $\begin{array}{c}35-44 \\
(N=413)\end{array}$ & $\begin{array}{c}45-54 \\
(N=399)\end{array}$ & $\begin{array}{c}55+ \\
(N=753)\end{array}$ & $p^{*}$ \\
\hline $\begin{array}{l}\text { Stories where } \\
\text { facts are spun or } \\
\text { twisted to push a } \\
\text { particular agenda }\end{array}$ & $66 \%$ & $68 \%$ & $71 \%$ & $76 \%$ & $82 \%$ & $<.001$ & $61 \%$ & $58 \%$ & $65 \%$ & $70 \%$ & $82 \%$ & $<.001$ & $74 \%$ & $68 \%$ & $72 \%$ & $79 \%$ & $83 \%$ & $<.001$ \\
\hline $\begin{array}{l}\text { Stories that are } \\
\text { completely made } \\
\text { up for political or } \\
\text { commercial } \\
\text { reasons }\end{array}$ & $66 \%$ & $68 \%$ & $71 \%$ & $76 \%$ & $82 \%$ & $<.001$ & $58 \%$ & $61 \%$ & $64 \%$ & $69 \%$ & $78 \%$ & $<.001$ & $68 \%$ & $61 \%$ & $68 \%$ & $75 \%$ & $80 \%$ & $<.001$ \\
\hline $\begin{array}{l}\text { Poor journalism } \\
\text { (factual mistakes, } \\
\text { dumbed-down } \\
\text { stories, } \\
\text { misleading head- } \\
\text { lines/clickbait) }\end{array}$ & $60 \%$ & $64 \%$ & $66 \%$ & $68 \%$ & $76 \%$ & $<.001$ & $63 \%$ & $62 \%$ & $65 \%$ & $68 \%$ & $78 \%$ & $<.001$ & $62 \%$ & $60 \%$ & $62 \%$ & $72 \%$ & $75 \%$ & $<.001$ \\
\hline $\begin{array}{l}\text { The use of the } \\
\text { term fake news } \\
\text { (e.g., by } \\
\text { politicians, } \\
\text { others) to } \\
\text { discredit news } \\
\text { media they don't } \\
\text { like }\end{array}$ & $54 \%$ & $56 \%$ & $54 \%$ & $59 \%$ & $68 \%$ & $<.001$ & $51 \%$ & $53 \%$ & $53 \%$ & $58 \%$ & $69 \%$ & $<.001$ & $64 \%$ & $58 \%$ & $59 \%$ & $71 \%$ & $71 \%$ & $<.001$ \\
\hline $\begin{array}{l}\text { Headlines that } \\
\text { look like news } \\
\text { stories but turn } \\
\text { out to be } \\
\text { advertisements }\end{array}$ & $36 \%$ & $41 \%$ & $39 \%$ & $39 \%$ & $54 \%$ & $<.001$ & $36 \%$ & $39 \%$ & $37 \%$ & $43 \%$ & $53 \%$ & $<.001$ & $54 \%$ & $47 \%$ & $46 \%$ & $52 \%$ & $59 \%$ & $<.001$ \\
\hline $\begin{array}{l}\text { Stories that are } \\
\text { completely made } \\
\text { up to make } \\
\text { people laugh } \\
\text { (satire) }\end{array}$ & $31 \%$ & $25 \%$ & $26 \%$ & $28 \%$ & $34 \%$ & .046 & $29 \%$ & $29 \%$ & $30 \%$ & $30 \%$ & $41 \%$ & $<.001$ & $31 \%$ & $30 \%$ & $33 \%$ & $34 \%$ & $36 \%$ & .033 \\
\hline
\end{tabular}

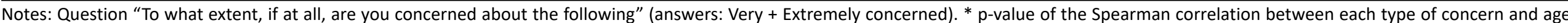
(within each country). Source: Adapted from the Reuters Institute Digital News Report survey 2018, conducted by YouGov.

Media and Communication, 2021, Volume 9, Issue 1, Pages 333-347 
Table 4. Concern about disinformation due to political position.

\begin{tabular}{|c|c|c|c|c|c|c|c|c|c|c|c|c|}
\hline & \multicolumn{4}{|c|}{ Argentina } & \multicolumn{4}{|c|}{ Chile } & \multicolumn{4}{|c|}{ Spain } \\
\hline & $\begin{array}{c}\text { Left } \\
(\mathrm{N}=204)\end{array}$ & $\begin{array}{c}\text { Centre } \\
(\mathrm{N}=1138)\end{array}$ & $\begin{array}{c}\text { Right } \\
(N=201)\end{array}$ & $p^{*}$ & $\begin{array}{c}\text { Left } \\
(\mathrm{N}=313)\end{array}$ & $\begin{array}{c}\text { Centre } \\
(\mathrm{N}=934)\end{array}$ & $\begin{array}{c}\text { Right } \\
(\mathrm{N}=285)\end{array}$ & $p^{*}$ & $\begin{array}{c}\text { Left } \\
(\mathrm{N}=585)\end{array}$ & $\begin{array}{c}\text { Centre } \\
(N=1108)\end{array}$ & $\begin{array}{c}\text { Right } \\
(N=143)\end{array}$ & $p^{*}$ \\
\hline $\begin{array}{l}\text { Stories where facts } \\
\text { are spun or twisted } \\
\text { to push a particular } \\
\text { agenda }\end{array}$ & $80 \%$ & $78 \%$ & $72 \%$ & .095 & $76 \%$ & $75 \%$ & $68 \%$ & .039 & $80 \%$ & $78 \%$ & $75 \%$ & .381 \\
\hline $\begin{array}{l}\text { Stories that are } \\
\text { completely made up } \\
\text { for political or } \\
\text { commercial reasons }\end{array}$ & $82 \%$ & $77 \%$ & $66 \%$ & $<.001$ & $76 \%$ & $73 \%$ & $65 \%$ & .006 & $75 \%$ & $73 \%$ & $74 \%$ & .440 \\
\hline $\begin{array}{l}\text { Poor journalism } \\
\text { (factual mistakes, } \\
\text { dumbed-down } \\
\text { stories, misleading } \\
\text { headlines/clickbait) }\end{array}$ & $73 \%$ & $72 \%$ & $70 \%$ & .634 & $75 \%$ & $74 \%$ & $70 \%$ & .277 & $70 \%$ & $68 \%$ & $71 \%$ & .569 \\
\hline $\begin{array}{l}\text { The use of the term } \\
\text { fake news (e.g., by } \\
\text { politicians, others) } \\
\text { to discredit news } \\
\text { media they don't like }\end{array}$ & $63 \%$ & $62 \%$ & $60 \%$ & .687 & $67 \%$ & $64 \%$ & $53 \%$ & $<.001$ & $72 \%$ & $65 \%$ & $64 \%$ & .009 \\
\hline $\begin{array}{l}\text { Headlines that look } \\
\text { like news stories but } \\
\text { turn out to be } \\
\text { advertisements }\end{array}$ & $52 \%$ & $45 \%$ & $42 \%$ & 0.69 & $46 \%$ & $46 \%$ & $45 \%$ & .935 & $56 \%$ & $52 \%$ & $50 \%$ & .290 \\
\hline $\begin{array}{l}\text { Stories that are } \\
\text { completely made up } \\
\text { to make people } \\
\text { laugh (satire) }\end{array}$ & $30 \%$ & $28 \%$ & $30 \%$ & .506 & $31 \%$ & $34 \%$ & $35 \%$ & .711 & $32 \%$ & $35 \%$ & $42 \%$ & .075 \\
\hline
\end{tabular}


Table 5. Actions against disinformation by country.

\begin{tabular}{|c|c|c|c|c|}
\hline & $\begin{array}{l}\text { Argentina } \\
(N=2006)\end{array}$ & $\begin{array}{c}\text { Chile } \\
(N=2004)\end{array}$ & $\begin{array}{c}\text { Spain } \\
(N=2005)\end{array}$ & $p^{*}$ \\
\hline $\begin{array}{l}\text { I checked a number of different sources to see whether } \\
\text { a news story was reported in the same way }\end{array}$ & $60 \%^{a}$ & $63 \%^{a}$ & $56 \%^{a}$ & $<.001$ \\
\hline $\begin{array}{l}\text { I decided not to share a news story because I was } \\
\text { unsure about its accuracy }\end{array}$ & $52 \%^{b}$ & $50 \%^{b}$ & $40 \%^{b}$ & $<.001$ \\
\hline $\begin{array}{l}\text { I discussed a news story with a person I trust because } \\
\text { I was unsure about its accuracy }\end{array}$ & $37 \% d$ & $40 \%{ }^{c}$ & $37 \%$ b & .090 \\
\hline $\begin{array}{l}\text { I stopped paying attention to news shared by someone } \\
\text { because I am unsure whether I trust that person }\end{array}$ & $39 \%^{c}$ & $40 \%^{c}$ & $28 \%^{c}$ & $<.001$ \\
\hline $\begin{array}{l}\text { I stopped using certain news sources because I was } \\
\text { unsure about the accuracy of their reporting }\end{array}$ & $35 \% d$ & $36 \% d$ & $29 \%^{c}$ & $<.001$ \\
\hline $\begin{array}{l}\text { I started relying more on sources of news that are } \\
\text { considered more reputable }\end{array}$ & $27 \%$ e & $27 \%{ }^{\mathrm{e}}$ & $20 \%{ }^{d}$ & $<.001$ \\
\hline
\end{tabular}

Notes: Question "Have you done any of the following in the last year? Please select all that apply." Within each country, different superscripts indicate a statistically significant $(p<.05)$ difference in percentages, according to the McNemar's test $\left({ }^{a}>^{b}>{ }^{c}>{ }^{d}>{ }^{e}\right) . *^{*} p$-value of the Chi-squared test. for the inter-country comparison. Source: Adapted from the Reuters Institute Digital News Report survey 2019, conducted by YouGov.

regression, a greater number of actions were carried out by participants with post-secondary education, by those who access news more frequently, by those who have greater interest in political news, and by Argentinians and Chileans.

\section{Discussion and Conclusion}

In the previous sections, we comparatively analysed the perceptions of disinformation by digital users in three Spanish-speaking countries.

After analysing the data, and in response to the first research question (RQ1), Internet users from Argentina, Chile, and Spain agree both on the types of problematic information that they consider to be of most concern and on their ranking, considering the use of news to push particular agendas as the most worrying. These are closely followed by stories that are completely made up for political or commercial reasons, and thirdly, by instances of poor journalism such as factual mistakes and misleading headlines. Regardless, people see the difference between fake news and news as one of degree rather than a clear distinction, following research by Nielsen and Graves (2017) who conducted focus groups on different countries combined with Reuters Digital News Reports. Thus, from an audience perspective, these modalities of problematic information seem to be part of a broader discontent with the news industry, as well as platform companies and politicians.

Given these remarkable similarities in general perceptions of problematic information, the differences found among the analysed sociodemographic segments are even more relevant (RQ2). A general index of 'Concern about disinformation' showed that it is higher among women, older people, those with high interest in political news, left-wingers, and Spaniards.

In response to RQ3, participants in the three countries also react similarly regarding the actions taken to protect themselves against disinformation. They indicate the same order of measures to combat this phenomenon, and with similar frequency in Argentina, Chile, and Spain-although to a lesser extent in Spain. The checking of different sources is the main measure that respondents from the three countries take against disinformation, followed by avoiding viralizing news that is not entirely reliable and discussing news stories with interpersonal contacts when its accuracy is unclear. The importance given to fact-checking partially matches previous research (Wagner \& Boczkowski, 2019). It works as an 'external act of authentication' (Tandoc, Ling, et al., 2018) complementing other measures such as the consulting of trusted peers. It is also important to note that surveyees gave importance to not being a propagator of fake news. Even if this is due to a possible social desirability bias, it is relevant as this constitutes one of the basic actions of media literacy against disinformation.

Considering how the variables of age, gender, and political position influence perceptions and actions to combat disinformation (RQ2), we pointed out that the concern about disinformation increases as the participants age. This is a finding that concurs with other research (Guess et al., 2019). As might be expected, those who are more interested in political news are also more concerned about disinformation (Chadwick \& Vaccari, 2019). Regarding gender, there are few differences (as can be seen in more detail in Supplementary File, Tables A and B). Men and women share similar concerns about disinformation and ranked them in the same 


\section{COGITATIO}

Table 6. Actions against disinformation by age.

\begin{tabular}{|c|c|c|c|c|c|c|c|c|c|c|c|c|c|c|c|c|c|c|}
\hline & \multicolumn{6}{|c|}{ Argentina } & \multicolumn{6}{|c|}{ Chile } & \multicolumn{6}{|c|}{ Spain } \\
\hline & $\begin{array}{c}18-24 \\
(N=297)\end{array}$ & $\begin{array}{c}25-34 \\
(N=413)\end{array}$ & $\begin{array}{c}35-44 \\
(N=397)\end{array}$ & $\begin{array}{c}45-54 \\
(N=305)\end{array}$ & $\begin{array}{c}55+ \\
(N=594)\end{array}$ & $p^{*}$ & $\begin{array}{c}18-24 \\
(N=271)\end{array}$ & $\begin{array}{c}25-34 \\
(N=413)\end{array}$ & $\begin{array}{c}35-44 \\
(N=357)\end{array}$ & $\begin{array}{c}45-54 \\
(N=355)\end{array}$ & $\begin{array}{c}55+ \\
(N=609)\end{array}$ & $p^{*}$ & $\begin{array}{c}18-24 \\
(N=164)\end{array}$ & $\begin{array}{c}25-34 \\
(N=283)\end{array}$ & $\begin{array}{c}35-44 \\
(N=399)\end{array}$ & $\begin{array}{c}45-54 \\
(N=399)\end{array}$ & $\begin{array}{c}55+ \\
(N=760)\end{array}$ & $p^{*}$ \\
\hline $\begin{array}{l}\text { I checked a number } \\
\text { of different sources } \\
\text { to see whether a } \\
\text { news story was } \\
\text { reported in the } \\
\text { same way }\end{array}$ & $57 \%$ & $59 \%$ & $61 \%$ & $64 \%$ & $60 \%$ & .337 & $58 \%$ & $60 \%$ & $60 \%$ & $67 \%$ & $68 \%$ & $<.001$ & $55 \%$ & $52 \%$ & $56 \%$ & $57 \%$ & $57 \%$ & 1.83 \\
\hline $\begin{array}{l}\text { I decided not to } \\
\text { share a news story } \\
\text { because I was } \\
\text { unsure about its } \\
\text { accuracy }\end{array}$ & $49 \%$ & $52 \%$ & $54 \%$ & $51 \%$ & $54 \%$ & .282 & $51 \%$ & $53 \%$ & $47 \%$ & $49 \%$ & $49 \%$ & .310 & $37 \%$ & $36 \%$ & $45 \%$ & $40 \%$ & $39 \%$ & .923 \\
\hline $\begin{array}{l}\text { I discussed a news } \\
\text { story with a person } \\
\text { I trust because } \\
\text { I was unsure about } \\
\text { its accuracy }\end{array}$ & $39 \%$ & $40 \%$ & $36 \%$ & $30 \%$ & $36 \%$ & .080 & $44 \%$ & $40 \%$ & $32 \%$ & $43 \%$ & $40 \%$ & .956 & $42 \%$ & $41 \%$ & $35 \%$ & $37 \%$ & $35 \%$ & .014 \\
\hline $\begin{array}{l}\text { I stopped paying } \\
\text { attention to news } \\
\text { shared by someone } \\
\text { because I am } \\
\text { unsure whether } \\
\text { I trust that person }\end{array}$ & $34 \%$ & $39 \%$ & $39 \%$ & $40 \%$ & $41 \%$ & .084 & $35 \%$ & $34 \%$ & $38 \%$ & $44 \%$ & $45 \%$ & $<.001$ & $34 \%$ & $24 \%$ & $24 \%$ & $27 \%$ & $30 \%$ & .500 \\
\hline $\begin{array}{l}\text { I stopped using } \\
\text { certain news } \\
\text { sources because } \\
\text { I was unsure about } \\
\text { the accuracy of } \\
\text { their reporting }\end{array}$ & $36 \%$ & $37 \%$ & $33 \%$ & $35 \%$ & $35 \%$ & .737 & $33 \%$ & $35 \%$ & $34 \%$ & $36 \%$ & $38 \%$ & .145 & $26 \%$ & $30 \%$ & $27 \%$ & $29 \%$ & $30 \%$ & .407 \\
\hline $\begin{array}{l}\text { I started relying } \\
\text { more on sources of } \\
\text { news that are } \\
\text { considered more } \\
\text { reputable }\end{array}$ & $26 \%$ & $26 \%$ & $24 \%$ & $22 \%$ & $31 \%$ & .073 & $31 \%$ & $24 \%$ & $25 \%$ & $23 \%$ & $30 \%$ & .270 & $20 \%$ & $24 \%$ & $19 \%$ & $18 \%$ & $19 \%$ & .481 \\
\hline
\end{tabular}


Table 7. Actions against disinformation by political position.

\begin{tabular}{|c|c|c|c|c|c|c|c|c|c|c|c|c|}
\hline & \multicolumn{4}{|c|}{ Argentina } & \multicolumn{4}{|c|}{ Chile } & \multicolumn{4}{|c|}{ Spain } \\
\hline & $\begin{array}{c}\text { Left } \\
(\mathrm{N}=179)\end{array}$ & $\begin{array}{c}\text { Centre } \\
(\mathrm{N}=897)\end{array}$ & $\begin{array}{c}\text { Right } \\
(\mathrm{N}=177)\end{array}$ & $\mathrm{p}^{*}$ & $\begin{array}{c}\text { Left } \\
(\mathrm{N}=267)\end{array}$ & $\begin{array}{c}\text { Centre } \\
(\mathrm{N}=787)\end{array}$ & $\begin{array}{c}\text { Right } \\
(\mathrm{N}=248)\end{array}$ & $\mathrm{p}^{*}$ & $\begin{array}{c}\text { Left } \\
(\mathrm{N}=547)\end{array}$ & $\begin{array}{c}\text { Centre } \\
(\mathrm{N}=867)\end{array}$ & $\begin{array}{c}\text { Right } \\
(\mathrm{N}=218)\end{array}$ & $\mathrm{p}^{*}$ \\
\hline $\begin{array}{l}\text { I checked a number of } \\
\text { different sources to see } \\
\text { whether a news story } \\
\text { was reported in the } \\
\text { same way }\end{array}$ & $68 \%$ & $66 \%$ & $62 \%$ & .641 & $72 \%$ & $70 \%$ & $63 \%$ & .118 & $58 \%$ & $58 \%$ & $55 \%$ & .461 \\
\hline $\begin{array}{l}\text { I decided not to share a } \\
\text { news story because I was } \\
\text { unsure about its } \\
\text { accuracy }\end{array}$ & $56 \%$ & $58 \%$ & $53 \%$ & .558 & $54 \%$ & $55 \%$ & $55 \%$ & .965 & $41 \%$ & $43 \%$ & $37 \%$ & .364 \\
\hline $\begin{array}{l}\text { I discussed a news story } \\
\text { with a person I trust } \\
\text { because I was unsure } \\
\text { about its accuracy }\end{array}$ & $44 \%$ & $41 \%$ & $32 \%$ & .025 & $44 \%$ & $42 \%$ & $43 \%$ & .920 & $38 \%$ & $39 \%$ & $36 \%$ & .781 \\
\hline $\begin{array}{l}\text { I stopped paying } \\
\text { attention to news shared } \\
\text { by someone because } \\
\text { I am unsure whether } \\
\text { I trust that person }\end{array}$ & $43 \%$ & $44 \%$ & $37 \%$ & .203 & $49 \%$ & $44 \%$ & $44 \%$ & .276 & $29 \%$ & $30 \%$ & $29 \%$ & .859 \\
\hline $\begin{array}{l}\text { I stopped using certain } \\
\text { news sources because } \\
\text { I was unsure about the } \\
\text { accuracy of their } \\
\text { reporting }\end{array}$ & $49 \%$ & $39 \%$ & $37 \%$ & 0.14 & $47 \%$ & $38 \%$ & $38 \%$ & .035 & $33 \%$ & $30 \%$ & $34 \%$ & .226 \\
\hline $\begin{array}{l}\text { I started relying more on } \\
\text { sources of news that are } \\
\text { considered more } \\
\text { reputable }\end{array}$ & $30 \%$ & $30 \%$ & $38 \%$ & .083 & $25 \%$ & $32 \%$ & $33 \%$ & .064 & $18 \%$ & $22 \%$ & $22 \%$ & .098 \\
\hline
\end{tabular}

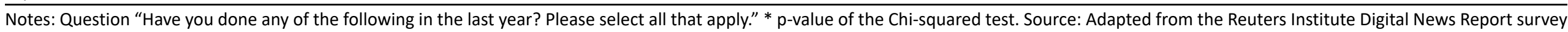
2019, conducted by YouGov. 
Table 8. Predictors associated with concern about misinformation and with actions against disinformation.

\begin{tabular}{|c|c|c|c|c|c|c|c|c|}
\hline & \multicolumn{4}{|c|}{ Concern about misinformation $^{a}$} & \multicolumn{4}{|c|}{ Actions against disinformation ${ }^{b}$} \\
\hline & $\mathrm{N}$ & Mean $(S D)$ & $p^{c}$ & $\mathrm{~B}(95 \% \mathrm{Cl})^{d}$ & $\mathrm{~N}$ & Mean $(S D)$ & $p^{c}$ & $\mathrm{~B}(95 \% \mathrm{Cl})^{d}$ \\
\hline \multicolumn{9}{|l|}{ Gender } \\
\hline Male & 2362 & $21.88(4.98)$ & .004 & (ref) & 2160 & $2.58(1.63)$ & .745 & (ref) \\
\hline Female & 2250 & $22.30(4.83)$ & & 0.59 (0.31 to 0.87$)$ & 2052 & $2.60(1.53)$ & & $0.03(-0.06$ to 0.13$)$ \\
\hline \multicolumn{9}{|l|}{ Age } \\
\hline $18-44$ & 2191 & $21.44(4.84)$ & $<.001$ & (ref) & 1978 & $2.59(1.54)$ & .956 & (ref) \\
\hline $45+$ & 2421 & $22.67(4.89)$ & & 1.00 (0.72 to 1.28$)$ & 2234 & $2.59(1.62)$ & & $0.00(-0.09$ to 0.10$)$ \\
\hline \multicolumn{9}{|l|}{ Post-secondary education } \\
\hline No & 1358 & $22.00(5.08)$ & .436 & (ref) & 2387 & $2.50(1.59)$ & $<.001$ & (ref) \\
\hline Yes & 3254 & $22.12(4.84)$ & & $-0.05(-0.35$ to 0.26$)$ & 1825 & $2.70(1.56)$ & & 0.17 (0.08 to 0.27$)$ \\
\hline \multicolumn{9}{|l|}{ Access to news } \\
\hline Once per day or less & 1699 & $21.71(5.03)$ & $<.001$ & (ref) & 1580 & $2.28(1.55)$ & $<.001$ & (ref) \\
\hline More than once per day & 2913 & $22.31(4.82)$ & & $0.27(-0.03$ to 0.56$)$ & 2632 & $2.77(1.57)$ & & $0.38(0.29$ to 0.48$)$ \\
\hline \multicolumn{9}{|l|}{ Interest in political news } \\
\hline Little & 1885 & $20.93(5.21)$ & $<.001$ & (ref) & 2187 & $2.40(1.55)$ & $<.001$ & (ref) \\
\hline Much & 2727 & $22.88(4.52)$ & & 1.75 (1.45 to 2.05$)$ & 2025 & $2.79(1.60)$ & & $0.34(0.24$ to 0.44$)$ \\
\hline \multicolumn{9}{|l|}{ Political self-position } \\
\hline Left & 1032 & $22.54(4.90)$ & $<.001$ & (ref) & 984 & $2.53(1.58)$ & .241 & (ref) \\
\hline Centre & 2992 & $22.05(4.80)$ & & $-0.27(-0.61$ to 0.08$)$ & 2589 & $2.62(1.57)$ & & $-0.01(-0.12$ to 0.11$)$ \\
\hline Right & 588 & $21.47(5.40)$ & & $-0.61(-1.10$ to -0.11$)$ & 639 & $2.54(1.64)$ & & $-0.11(-0.26$ to 0.04$)$ \\
\hline \multicolumn{9}{|l|}{ Country } \\
\hline Argentina & 1447 & $21.92(4.88)$ & $<.001$ & (ref) & 1259 & $2.79(1.57)$ & $<.001$ & (ref) \\
\hline Chile & 1387 & $21.61(5.41)$ & & $-0.03(-0.39$ to 0.33$)$ & 1297 & $2.83(1.62)$ & & 0.07 ( -0.05 to 0.19$)$ \\
\hline Spain & 1778 & $22.60(4.46)$ & & 0.44 (0.10 to 0.78$)$ & 1656 & $2.24(1.50)$ & & $-0.57(-0.68$ to -0.45$)$ \\
\hline
\end{tabular}

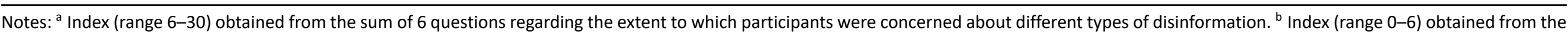

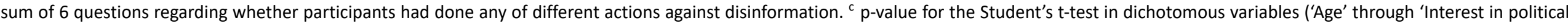

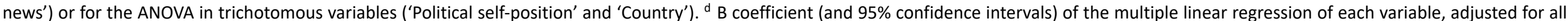
variables in the first column. Adjusted R-squared $=.06$ (for the model predicting 'Concern about misinformation') and .07 (for the model predicting 'Actions against disinformation'). 
order of importance. This also seems to agree with previous studies (Wolverton \& Stevens, 2019), which found no significant differences in this regard. However, and despite this relative uniformity, there are different reactions against disinformation. Men and women reported taking different measures to protect themselves from misinformation, although they are concerned about the same elements. While men rely more on the reputation of the source as a preventive action, women appear to be more active in taking steps to protect themselves against fake news, checking different sources to compare, and/or avoiding sharing a news story if they are not sure of its adequacy. In other words, men and women agree more in the diagnosis of the problem, than in the path followed to solve it. Following Giglietto et al. (2019), it could be said that when women receive disinformation, they avoid becoming propagators of it to a greater degree than men.

Finally, regarding ideological self-positioning as a variable for interpreting the phenomenon, we see that those who define themselves as 'right-wing' or 'centre' tend to worry slightly less about the problems of disinformation than those that claim to be 'left-wing.' This was clearly observed in the Argentinian and Chilean cases. This is not a finding against what previous research has found regarding US voters, as one might think on first impulse: Those studies that analysed the 2016 US presidential election and found that American right-wing voters were more vulnerable to disinformation than the left-wing voters, were focused on content and reception (Allcott \& Gentzkow, 2017; Grinberg et al., 2019; Mckay \& Tenove, 2020). Instead, our findings are based on users' perceptions. They show that those who see themselves as leftists are more aware of the problem of disinformation, and that circumstances might make them better protected against the phenomena.

There were remarkable similarities in how users handle problematic information in the three countries analysed. Hasty conclusions should be avoided as they could lead to generalizations about the phenomenon of disinformation in Iberoamerica; it would be worth conducting a more in-depth investigation into the differences by country and their reasons, considering previous studies. For example, in the Venezuelan case (Serrano-Puche et al., 2021), a different hierarchization and intensity was found in the modalities of 'problematic information,' where among other differences, poor journalism was users' main concern. In short, it is important to continue researching the geographic and demographic variables that best allow the identification of information vulnerability, since the clear identification of the groups most vulnerable to disinformation could suggest effective measures to mitigate its negative effects.

\section{Acknowledgments}

We would like to thank Dr. Alfonso Osorio for his valuable insight and statistical and methodological advice.
We also thank Beatriz Nieto Fernández for her precious help in proofreading the manuscript. Finally, we show our gratitude to the reviewers for their valuable comments and suggestions.

\section{Conflict of Interests}

The authors declare no conflict of interests.

\section{Supplementary Material}

Supplementary material for this article is available online in the format provided by the author (unedited).

\section{References}

Allcott, H., \& Gentzkow, M. (2017). Social media and fake news in the 2016 election. Journal of Economic Perspectives, 31(2), 211-236. https://doi.org/10.1257/ jep.31.2.211

Aufderheide, P. (1993). Media literacy: A report of the national leadership conference on media literacy. Washington, DC: The Aspen Institute.

Bail, C. A., Guay, B., Maloney, E., Combs, A., Hillygus, D. S., Merhout, F., . . \& Volfovsky, A. (2020). Assessing the Russian Internet Research Agency's impact on the political attitudes and behaviors of American Twitter users in late 2017. Proceedings of the National Academy of Sciences, 117(1), 243-250.

Chadwick, A., \& Vaccari, C. (2019). News sharing on UK social media: Misinformation, disinformation, and correction. Loughborough: Loughborough University-Online Civic Culture Centre.

Egelhofer, J. L., \& Lecheler, S. (2019). Fake news as a two-dimensional phenomenon: A framework and research agenda. Annals of the International Communication Association, 43(2), 97-116. https://doi.org/ 10.1080/23808985.2019.1602782

Fernández, C. B., \& Rodríguez-Virgili, J. (2019). Electors are from Facebook, political geeks are from Twitter: Political information consumption in Argentina, Spain and Venezuela. KOME, 7(1), 42-62. https://doi. org/10.17646/KOME.75698.62

Figueira, J., \& Santos, S. (2019). Percepción de las noticias falsas en universitarios de Portugal: Análisis de su consumo y actitudes [Perceptions about fake news in Portuguese higher education students: An analysis of consumption and attitudes]. El Profesional de la Información, 28(3).

Freelon, D., Bossetta, M., Wells, C., Lukito, J., Xia, Y., \& Adams, K. (2020). Black trolls matter: Racial and ideological asymmetries in social media disinformation. Social Science Computer Review. Advance online publication. https://doi.org/10.1177/08944 39320914853

Freelon, D., \& Wells, C. (2020). Disinformation as political communication. Political Communication, 37(2), 145-156. https://doi.org/10.1080/10584609. 
2020.1723755

Giglietto, F., lannelli, L., Valeriani, A., \& Rossi, L. (2019). 'Fake news' is the invention of a liar: How false information circulates within the hybrid news system. Current Sociology, 67(4), 625-642. https://doi.org/ 10.1177/0011392119837536

Grinberg, N., Joseph, K., Friedland, L., Swire-Thompson, B., \& Lazer, D. (2019). Fake news on Twitter during the 2016 U.S. presidential election. Science, 363(6425), 374-378. https://doi.org/10.1126/ science.aau 2706

Guallar, J., Codina, L., Freixa, P., \& Pérez-Montoro, M. (2020). Desinformación, bulos, curación y verificación: Revisión de estudios en iberoamérica 2017-2020 [Misinformation, hoaxes, curation and verification: Review of studies in Iberomerica 2017-2020]. Telos: Revista de Estudios Interdisciplinarios en Ciencias Sociales, 22(3), 595-613. www.doi.org/10.36390/telos223.09

Guess, A., Nagler, J., \& Tucker, J. (2019). Less than you think: Prevalence and predictors of fake news dissemination on Facebook. Science Advances, 5(1), eaau4586. https://doi.org/10.1126/sciadv.aau4586

Ha, L., Perez, L. A., \& Ray, R. (2019). Mapping recent development in scholarship on fake news and misinformation, 2008 to 2017: Disciplinary contribution, topics, and impact. American Behavioral Scientist, 65(2), 290-315. https://doi.org/10.1177/ 0002764219869402

High Level Expert Group on Fake News and Disinformation. (2018). A multi-dimensional approach to disinformation: Report of the independent high level group on fake news and online disinformation. Brussels: European Commission. Retrieved from https://ec.europa.eu/digital-single-market/en/ news/final-report-high-level-expert-group-fakenews-and-online-disinformation

Hjorth, F., \& Adler-Nissen, R. (2019). Ideological asymmetry in the reach of pro-Russian digital disinformation to United States audiences. Journal of Communication, 69(2), 168-192. https://doi.org/10.1093/joc/ jqz006

Howard, P. N., Ganesh, B., Liotsiou, D., Kelly, J., \& Francois, C. (2018). The IRA, social media and political polarization in the United States, 2012-2018. Oxford: University of Oxford.

Humprecht, E., Esser, F., \& Van Aelst, P. (2020). Resilience to online disinformation: A framework for crossnational comparative research. The International Journal of Press/Politics, 25(3), 493-516. https://doi. org/10.1177/1940161219900126

Internet World Stats. (2020). World Internet users and population stats. Internet World Stats. Retrieved from www.internetworldstats.com

Iyengar, S., \& Hahn, K. S. (2009). Red media, blue media: Evidence of ideological selectivity in media use. Journal of Communication, 59(1), 19-39.

Jack, C. (2017). Lexicon of lies: Terms for problematic information. New York, NY: Data \& Society Research Institute. Retrieved from https://datasociety.net/ library/lexicon-of-lies

Khaldarova, I., \& Pantti, M. (2016). Fake news. Journalism Practice, 10(7), 891-901. https://doi.org/ 10.1080/17512786.2016.1163237

Klurfeld, J., \& Schneider, H. (2014). News literacy: Teaching the internet generation to make reliable information choices. Washington, DC: The Brookings Institution. Retrieved from https://www.brookings.edu/ research/news-literacy-teaching-the-internetgeneration-to-make-reliable-information-choices

Kunda, Z. (1990). The case for motivated reasoning. Psychological Bulletin, 108(3), 480-498.

Lazer, D. M., Baum, M. A., Benkler, Y., Berinsky, A. J., Greenhill, K. M., Menczer, F., . . . \& Zittrain, J. L. (2018). The science of fake news. Science, 359(6380), 1094-1096.

Lewandowsky, S., Ecker, U. K. H., \& Cook, J. (2017). Beyond misinformation: Understanding and coping with the "post-truth" era. Journal of Applied Research in Memory and Cognition, 6(4), 353-369.

Livingstone, S. (2004). Media literacy and the challenge of new information and communication technologies. The Communication Review, 7(1), 3-14. https:// doi.org/10.1080/10714420490280152

Lord, C. G., \& Taylor, C. (2009). Biased assimilation: Effects of assumptions and expectations on the interpretation of new evidence. Social and Personality Psychology Compass, 3(5), 827-841.

McKay, S., \& Tenove, C. (2020). Disinformation as a threat to deliberative democracy. Political Research Quarterly. Advance online publication. https://doi.org/ 10.1177/1065912920938143

Meckstroth, T. W. (1975). Most different systems and most similar systems, a study in the logic of comparative inquiry. Comparative Political Studies, 8(2), 132-157.

Miller, M. L., \& Vaccari, C. (2020). Digital threats to democracy: Comparative lessons and possible remedies. The International Journal of Press/Politics, 25(3), 333-356. https://doi.org/10.1177/1940161 220922323

Molina, M. D., Sundar, S. S., Le, T., \& Lee, D. (2019). “Fake news" is not simply false information: A concept explication and taxonomy of online content. American Behavioral Scientist, 65(2), 180-212. https://doi. org/10.1177/0002764219878224

Morais, N. S., \& Cruz, M. (2020). Gender perception about fake news and disinformation: Case study with Portuguese higher education students. In L. Gómez Chova, A. López Martínez, \& I. Candel Torres (Eds.), EDULEARN20 Proceedings: 12th international conference on Education and New Learning Technologies (pp. 7746-7753). Valencia: International Academy of Technology, Education and Development. https:// doi.org/10.21125/edulearn.2020.1957

Nielsen, R. K., \& Graves, L. (2017). “News you don't 
believe": Audience perspectives on fake news. Oxford: Reuters Institute for the Study of Journalism.

Newman, N., Fletcher, R., Kalogeropoulos, A., Levy, D. A., \& Nielsen, R. (2018). Reuters Institute digital news report 2018. Oxford: Reuters Institute for the Study of Journalism. Retrieved from http://media.digitalnewsreport.org/wp-content/ uploads/2018/06/digital-news-report-2018.pdf

Newman, N., Fletcher, R., Kalogeropoulos, A., \& Nielsen, R. (2019). Reuters Institute digital news report 2019. Oxford: Reuters Institute for the Study of Journalism. Retrieved from https://reutersinstitute. politics.ox.ac.uk/sites/default/files/inline-files/ DNR_2019_FINAL.pdf

Reuter, C. A., Hartwig, K., Kirchner, J., \& Schlegel, N. (2019). Fake news perception in Germany: A representative study of people's attitudes and approaches to counteract disinformation. In V. Pipek \& T. Ludwig (Eds.), Proceedings of the International Conference on Wirtschaftsinformatik (pp. 1069-1083). Siegen: Ais.

Rojas, H., \& Valenzuela, S. (2019). A call to contextualize public opinion-based research in political communication. Political Communication, 36(4), 652-659. https://doi.org/10.1080/10584609.2019.1670897

Scheufele, D., \& Krause, N. (2019). Science audiences, misinformation, and fake news. Proceedings of the National Academy of Sciences, 116(16), 7662-7669.

Serrano-Puche, J., Fernández, C. B., \& Rodríguez-Virgili, J. (2018). Political information and incidental exposure in social media: The cases of Argentina, Chile, Spain and Mexico. Doxa Comunicación, 27, 19-42. https://doi.org/10.31921/doxacom.n27a1

Serrano-Puche, J., Fernández, C. B., \& Rodríguez-Virgili, J. (2021). Disinformation and news consumption in a polarized society: An analysis of the case of Venezuela. In D. Ramírez Plascencia, B. Carvalho Gurgel, \& A. Plaw (Eds.), The politics of technology in Latin America volume 2: Digital media, daily life and public engagement (pp. 161-178). London: Routledge.

Tandoc, E. C., Jr., Lim, Z. W., \& Ling, R. (2018). Defining "fake news": A typology of scholarly definitions. Digital Journalism, 6(2), 137-153. https://doi.org/ 10.1080/21670811.2017.1360143

Tandoc, E. C., Jr., Ling, R., Westlund, O., Duffy, A., Goh, D., \& Zheng Wei, L. (2018). Audiences' acts of authentication in the age of fake news: A conceptual framework. New Media \& Society, 20(8), 2745-2763. https://doi. org/10.1177/1461444817731756

Valenzuela, S., Halpern, D. I., Katz, J. E., \& Miranda, J. P. (2019). The paradox of participation versus misinformation: Social media, political engagement, and the spread of misinformation. Digital Journalism, 7(6), 802-823. https://doi.org/10.1080/21670811. 2019.1623701

Wagner, M. C., \& Boczkowski, P. B. (2019). The reception of fake news: The interpretations and practices that shape the consumption of perceived misinformation. Digital Journalism, 7(7), 870-885.

Wardle, C., \& Derakhshan, H. (2017). Information disorder: Toward an interdisciplinary framework for research and policymaking. Strasbourg: Council of Europe. Retrieved from https://rm.coe.int/ information-disorder-toward-an-interdisciplinaryframework-for-researc/168076277c

Wolverton, C., \& Stevens, D. (2019). The impact of personality in recognizing disinformation. Online Information Review, 44(1), 181-191. https://doi.org/ 10.1108/OIR-04-2019-0115

\section{About the Authors}

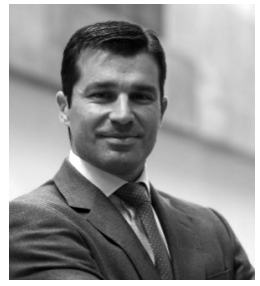

Jordi Rodríguez-Virgili is Associate Professor of Political Communication at the University of Navarra, where he serves as Associate Dean of Teaching Staff at the School of Communication. He is a researcher at the Center for Internet Studies and Digital Life at the UNAV. He has been Visiting International Scholar at The Graduate School of Political Management (George Washington University). Currently, his main inquiry interests are focused on media consumption, political communication, and disinformation.

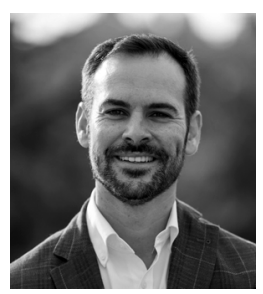

Javier Serrano-Puche is Associate Professor and Vice Dean for Academic Affairs at the School of Communication of the University of Navarra. He serves as a research fellow for the Center for Internet Studies and Digital Life at the same university and has performed extensive research on news consumption, media literacy and the relations between media and emotions. His recent publications include papers in Communications, International Journal of Communication, or Comunicar, and in publishing houses as Routledge, Palgrave MacMillan, and Springer.

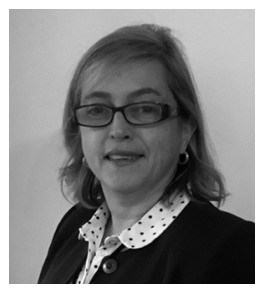

Carmen Beatriz Fernández is Guest Professor and Doctoral Candidate of the School of Communication at the University of Navarra, and Researcher at the Center for Internet Studies and Digital Life. She earned a MA in Business Administration (IESA, Venezuela) and a MA in Political Science, concentration on Electoral Campaigning (University of Florida, USA). Mrs Fernandez is CEO of DataStrategia consulting, and Co-Founder of the Organization of Latin American Political Consultants OCPLA. 